\title{
Development of Interactive Learning Media Based on Adobe Flash CS6 to Improve Spatial Abilities Students in Geometry Transformation
}

\author{
Dian Rizky Utami Tambunan, Edi Syahputra, Mangaratua M. Simanjorang \\ Postgraduate Mathematics Education study program, Medan State University \\ Medan, North Sumatra, Indonesia
}

\begin{abstract}
This research aims to 1) To develop interactive learning media based on Adobe Flash Pro CS6 on valid Geometry Transformation so that it can improve students' mathematic spatial abilities; 2) To develop interactive learning media based on Adobe Flash Pro CS6 on practical Geometry Transformation material so that it can improve students' mathematic spatial abilities; 3) To develop interactive learning media based on Adobe Flash Pro CS6 on effective Geometry Transformation so that it can improve students' mathematic spatial abilities; 4) To improve students' mathematic spatial abilities by using interactive learning media based on Adobe Flash Pro CS6 on Geometry Transformation. The results showed that: 1) The validation of learning media based on Adobe Flash Pro CS6 developed is in the 'Valid' category in terms of the analysis of the validity of the learning media by the validators with a total average score of 3.64 ; 2) The developed learning media based on Adobe Flash Pro CS6 meets the criteria for practicality of learning media in terms of analysis of the results of observations of learning implementation; 3) The learning media developed has met the defined effectiveness criteria; 4) Based on the normalized gain index, it was found that in the first trial there was an increase in the value with low criteria with a score of $0.28(\mathrm{~N}-\mathrm{Gain} \leq 0.3)$ and in the second trial there was an increase in the value with medium criteria with a score of $0.42(0.3<\mathrm{N}-\mathrm{Gain} \leq 0.7)$.
\end{abstract}

Keywords: Development of Learning Media, Adobe Flash CS6, Spatial Ability, Geometry Transformation

DOI: $10.7176 / \mathrm{JEP} / 12-8-09$

Publication date:March $31^{\text {st }} 2021$

\section{Introduction}

Learning media is defined as all physical tools in the form of software and hardware which are small parts of learning technology that must be created or developed, used and managed for the benefit of learning (Suprianto, Ahmadi, and Suminar, 2019). Learning media applied in learning is expected to be able to streamline the learning process to achieve learning objectives, namely improving student learning outcomes, and motivating students to learn. This statement is supported by Agung (2013) who states that the use of instructional media in the mathematics learning process is able to arouse desire, motivation, and stimulation of mathematics learning activities. The goal is to streamline the learning process so that learning objectives can be achieved. Therefore, to develop a good learning media must pay attention to four criteria, namely, relevance, convenience, attractiveness and usability.

The function of learning media can be determined based on the advantages of the media that appear in the learning process. The advantages of the media according to Gerlachd and Elly (Santyasa, 2007) and Murhaini (2016) are as follows: (1) fixative ability, namely the ability of the media to capture, store and represent an object or event; (2) manipulative ability, namely the ability of the media to present objects or events with various kinds of changes (manipulation) as needed, for example to change their size, speed, color, and to be presented repeatedly; (3) distributive ability, namely the ability of the media to reach large audiences simultaneously; (4) semantic ability, namely the ability of the media to concrete ideas and provide clarity so that knowledge and learning experiences can be clearer and easier to understand; (5) the function of the media as a source of learning, through the media students obtain messages and information so as to form new knowledge in students. Hamalik (2008) also expressed his opinion on the importance of media in learning, namely: (1) creating an effective learning situation; (2) is an integral part of the learning system; (3) accelerate the learning process and assist students in understanding the material presented by the teacher in the classroom; and (4) improving the quality of education. Based on the opinions above, it can be seen that learning media is a very important part of learning. Especially interactive learning media. As stated by Cholila, Purwanto, and Hidayanto (2019), interactive media-based mathematics learning aims to provide a memorable learning experience for students. So that learning in the classroom becomes more meaningful for students. Interactive can be defined as a process of empowering students to control the learning environment (Soenarto, 2009). In this context the intended learning environment is learning using computers. Interactive classification in the scope of multimedia learning does not lie in the hardware system, but rather refers to the characteristics of student learning in responding to stimuli displayed on a computer monitor screen (Istiqlal, 2017). 
Spatial ability is an ability that every student must have in learning mathematics, especially to understand spatial problems. According to the National Academy of Science (NAS) (Syahputra, 2011), spatial thinking is a collection of cognitive skills consisting of spatial concepts, representational tools and reasoning processes. NAS also added that this spatial ability is very useful for students in understanding the relationships and properties in geometry to solve math problems and problems of everyday life. When viewed from the context of everyday life, spatial abilities are also very necessary. This refers to the opinion of Barke and Engida (Syahputra, 2013) who state that spatial ability is a major intelligence factor that is not only important for mathematics and science, but also for the success of many professions, for example engineering, biomedical science, architecture, robotics and information systems. geographical. Guzel and Sener (2009) state, there are many definitions of spatial ability, but in general it is said that spatial ability is related to abilities that involve rotation, retention and transformation of visual information in spatial content which play an important role in mathematical creativity. In simple terms, Rahman (2012) explains that spatial ability is the ability of students to imagine, compare, predict, determine suitable objects, construct, present and find information from visual stimuli in a spatial context. Furthermore, Guzel and Sener (2009) stated that many studies have revealed that spatial abilities in mathematics provide several advantages such as increasing students' perceptual abilities, creating different contexts.

\section{Theoritical}

\section{Learning Media}

Prasetyo (Widodo and Wahyudin, 2018) said that learning media is a tool or equipment to implement a process that makes it easier for educators and students to carry out learning. Meanwhile, according to Miarso (Musfiqon, 2012), learning media is defined as a container for messages that are transmitted by the source or channel to the recipient of the message or target, the material presented is in the form of learning messages and the goal is the learning process. Musfiqon (2012) concludes the definition of learning media by saying that learning media is a physical or non-physical tool that is used as an intermediary between teachers and students to understand learning material more effectively and efficiently. Based on these opinions, it can be concluded that learning media are all forms of tools used to convey instructional messages / information from the source, in this case the teacher, to students which aims to streamline and streamline the learning process where there is reciprocal interaction between students. with the media, and vice versa.

According to Arsyad (2011) there are six criteria that teachers must pay attention to in selecting media, namely: in accordance with the objectives to be achieved; appropriate to support lessons that are facts, concepts, principles, or generalizations; practical, flexible and enduring; teachers are skilled at using it; target grouping; and technical quality. Warsita (Darmadi, 2017) argues that there are nine criteria in selecting instructional media, namely: the suitability of the media with objectives or competencies, with the type of knowledge, with objectives, availability of media, costs, ability of the media for the learning process, characteristics of the media concerned, time, and technical quality. In line with this opinion, Susilana and Riyana (2009) who define media as a source of learning suggest that the criteria for selecting and using media are: accuracy with learning objectives; support for the content of learning materials; easy access to learning resources or media; teacher skills in using it; availability of time; and conformity to the level of thinking of students.

\section{Adobe Flash Pro CS6}

Flash is an animation software launched by Macromedia which has now been adopted by Adobe, Inc .. Adobe Flash Pro CS6 is a version of Adobe Flash that has been updated from previous versions, namely Adobe Flash CS3 Pro, Adobe Flash CS4 Pro, and Adobe Flash Pro. CS5. Adobe Flash Pro CS6 is a software specially designed by Adobe and a professional standard authoring tool application program that can be used to create attractive animations and bitmaps for various purposes. Adobe Flash Pro CS6 is an animated graphic software that can create objects and animate them so that they can be immediately made into design objects without having to use other supporting tools such as Illustrator or Photoshop. Deiniatur (2019) said that Adobe Flash is software that has the ability to draw and animate it and is easy to learn. Not only in making animation, but also can be used for other purposes such as making games, presentations, building the web, learning animation, and even making films. In addition, this application also has high-extension features, so that media can be stored on your cellphone to make it more practical. Madcoms (2013) suggests that Adobe Flash Pro CS6 is good software to support interactive learning. Because, interactive learning media with the Adobe Flash Pro CS6 application can combine graphics, animation, sound, and have the ability to interact with users.

Based on the above opinions, it can be concluded that Adobe Flash Pro CS6 is a software owned by Adobe Inc. which is commonly used to create animations, presentations, games, films and other visual media as well as being used to create interactive learning media. Adobe Flash Pro CS6 is equipped with features that the previous version does not have, such as the bone tool used to create adventure animations by adding joint points to objects, the 3D Rotation tool for rotating objects, and changing the layout of the panels that make it easier for users to operate. 


\section{Spatial Ability}

Guay and Mc Daniel (Putri, 2017) define spatial abilities at two levels, namely first, low-level spatial abilities are abilities that require visualization of two-dimensional configurations but there is no mental configuration of the image, and second, high-level spatial abilities, namely abilities that are requires visualization of the threedimensional configuration, and there is mental manipulation of the image. Ifanda, Sugiarni, and Muharromah (2017) explain mathematical spatial abilities as the ability to imagine, determine, predict, present, construct, and find information from stimuli visually in the context of a room. This ability requires students to be able to state the position between the elements of space, identify and clarify images, imagine the shape or position of a geometric object seen from a certain perspective, construct and represent geometric models drawn on a flat plane in space, and investigate. geometric objects (Lestari \& Yudhanegara, 2015). In line with this, Ristontowi (2013) views spatial abilities as: (1) the ability of the eyes, especially with respect to color and space; (2) the ability to grasp and understand something using the five senses; (3) the ability to transform what is seen into other forms. Spatial ability is an abstract concept which includes spatial relationships, frame of reference, projective relationships, distance conservation, spatial representation, and mental rotation (Piaget \& Inhelder in Asis, Arsyad, and Alimuddin, 2015).

Maier (1998) divides spatial abilities into five aspects, namely:

1. Spatial Perception

Spatial perception refers to determining the direction in an event where a given pattern can be disturbing. Spatial perception is the ability to observe a shape and its parts in a horizontal or vertical position. Spatial perception refers to the way we perceive and interpret information that is collected and then processed through the five senses. The process of mental spatial perception is static, meaning that the relationship between subjects and objects changes, while the spatial relationships between objects do not change (Suparyan, 2007).

Based on the description above, it can be concluded that spatial perception is knowledge about an object obtained from direct contact with that object in previous learning experiences or knowledge.

\section{Spatial Visualization}

The word visualization comes from the word visualize which is defined as describing in imagination or imagining. Spatial visualization can be defined as the ability to describe, describe, or capture visible stimuli from the subject by imagining activities. Strong and Roger (2002) say that spatial visualization is the ability to manipulate objects in three-dimensional imaginary space and help represent objects from different points of view. Spatial visualization is described as the ability to imagine the rotation of objects or parts in three-dimensional space and mental manipulation and incorporation of stimuli consisting of one moving part or parts.

\section{Mental Rotation}

Maier (1998) states that mental rotation is the ability to describe two or three-dimensional shapes after being given a rotation. In line with this, Suparyan (2007) views that mental rotation includes the ability to rotate a space appropriately and quickly. In other words, mental rotation is the ability to produce dynamic images and visualize a moving configuration.

\section{Spatial Relation}

Based on the word relation which means relationship, spatial relations can be interpreted as the ability to express relationships in space. Pallegrini, et al. (Canturk-Gunham, 2009) states that spatial relations is the ability to quickly and accurately involve mental transformation or a rotational process of the identity of a pair of stimuli. Spatial relations can show how a person develops, forms images by only seeing clues, and how one should think in three dimensions.

\section{Spatial Orientation}

Spatial orientation is defined as the ability to recognize space in general. This ability is able to accurately predict changes in the orientation of an object. This ability is evaluated by tests that present two- and three-dimensional objects. It can be said that spatial orientation is the ability to recognize the form or arrangement of space in general by imagining changes in the perception of a given object.

\section{Methods}

\section{Research Pattern}

This research includes development research using the ADDIE development model to develop learning media based on Adobe Flash Pro CS6 on Geometry Transformation material and all necessary research instruments.

\section{Participants}

The subjects in this study were a number of students of class XI IPA 1 SMA Private Al-Manar Medan, amounting to 15 people in trial 1 and students / I class XI IPA 2 SMA Private Al-Manar Medan which also amounted to 15 people in trial II. 


\section{Data Collection Technique}

The instruments used in this study included: Mathematic Spatial Ability Test, Student Activity Observation Sheet, Teacher's Ability Observation Sheet to Manage Learning, Teacher and Student Response Questionnaires.

\section{Data Analysis}

The instruments used in this study included: Mathematic Spatial Ability Test, Student Activity Observation Sheet, Teacher's Ability Observation Sheet to Manage Learning, Teacher and Student Response Questionnaires.

\section{Result}

\section{Description of the Results of the Development of Interactive Learning Media Based on Adobe Flash Pro} CS6

Overall, the results of the first trial data analysis showed that the learning media developed did not meet all the success criteria set. Because there are still indicators of practicality and effectiveness that have not been achieved, namely the results of observations of the implementation of learning and the results of the final test of students' mathematical spatial abilities in the I trial. and the minimum score achieved by students is less than 70 and classical completeness has not reached $80 \%$ complete. However, other indicators of practicality and effectiveness have been met. From the results of observations, student activities have met the percentage of ideal time set and the teacher's ability to manage learning is classified as good $(3 \leq \mathrm{K} g \mathrm{~g}<4)$. Meanwhile, from the results of the response questionnaire, the teacher stated that the learning media developed were practical $\left(3 \leq \mathrm{R} \_\mathrm{g}<4\right)$ and students felt interested in learning using the developed learning media $\left(3 \leq \mathrm{R} \_\mathrm{s}<4\right)$. More complete data will be explained in the description of the practicality and effectiveness of learning media. After the results of the first trial are obtained, an evaluation stage will be carried out in which the researcher revises the learning media and / or devices developed based on the input obtained from the response questionnaire and observation sheet. It is intended that the media developed is in accordance with the objectives to be achieved. From the analysis of the results of the first trial, the researcher found several weaknesses that must be corrected so that this research can produce learning media and devices that meet all the valid, practical and effective criteria. After the revision was completed, the second trial using learning media (draft II) and the equipment was carried out in class XI IPA 2 of Al-Manar Medan Private High School with a total of 15 students. Trial II was conducted to measure whether the learning media and its devices met all the valid, practical, and effective criteria that had been determined.

Overall, the results of the second trial data analysis showed that the learning media developed had met all the valid, practical, and effective criteria set. Analysis of the validity of learning media based on Adobe Flash Pro CS6 developed in terms of the assessment of experts and practitioners regarding the learning media. The expert's assessment has been previously described at the development stage regarding the validation results of the validators, where the results show that the learning media developed is valid with an average value of 3.63 (category "Valid"). Based on this analysis, it can be said that the learning media developed are valid and ready to be used in learning.

The average score of the observation of the implementation of learning with learning media based on the developed Adobe Flash Pro CS6 is in the 'Poorly Executed' category with a score of 2.735. This score does not meet the criteria for the success of the practicality of learning media in terms of learning implementation.

Overall, the conclusions of the results of the first trial are as follows: 1) the level of implementation of learning using the learning media developed is in the category of 'Poorly Executed'; 2) the results of the students' mathematic spatial ability final test showed that learning with the developed media was not yet complete classically; 3 ) the results of observations of student activities have met the set activeness criteria; 4) the value of the teacher's ability to manage learning is good; and 5) teachers and students are interested in the learning media being developed.

\section{Description of the Increase in Students' Spatial Mathematic Ability}

To determine the increase in students 'mathematic spatial abilities, data were obtained from the results of the preliminary and final tests of students' mathematic spatial abilities in each trial. The increase in students' mathematic spatial abilities was obtained from the normalized gain index data as follows:

$$
N-\text { Gain }=\frac{S_{\text {post }}-S_{\text {pre }}}{S_{\text {max }}-S_{\text {pre }}}
$$

In the first trial, the initial test average value was 55.67 and the final test average was 68 , so the N-Gain value was as follows:

$$
\begin{aligned}
& N-\text { Gain }=\frac{S_{\text {post }}-S_{\text {pre }}}{S_{\text {max }}-S_{\text {pre }}} \\
& N-\text { Gain }=\frac{68-55,67}{100-55,67}
\end{aligned}
$$




$$
N-\operatorname{Gain}=\frac{12,33}{44,33}=0,28
$$

Whereas in the second trial, the initial test average value was 65.33 and the final test average was 80 , so that the N-Gain value was as follows :

$$
\begin{gathered}
N-\text { Gain }=\frac{S_{\text {post }}-S_{\text {pre }}}{S_{\text {max }}-S_{\text {pre }}} \\
N-\text { Gain }=\frac{80-65,33}{100-65,33} \\
N-\text { Gain }=\frac{14,67}{34,67}=0,42
\end{gathered}
$$

Based on the normalized gain index, it was found that in the first trial there was an increase in the value with low criteria $(\mathrm{N}-$ Gain $\leq 0.3)$ and in the second trial there was an increase in the value with medium criteria $(0.3$ $<\mathrm{N}-$ Gain $\leq 0.7)$. The increase in mathematic spatial abilities can be seen in Figure 1 below:

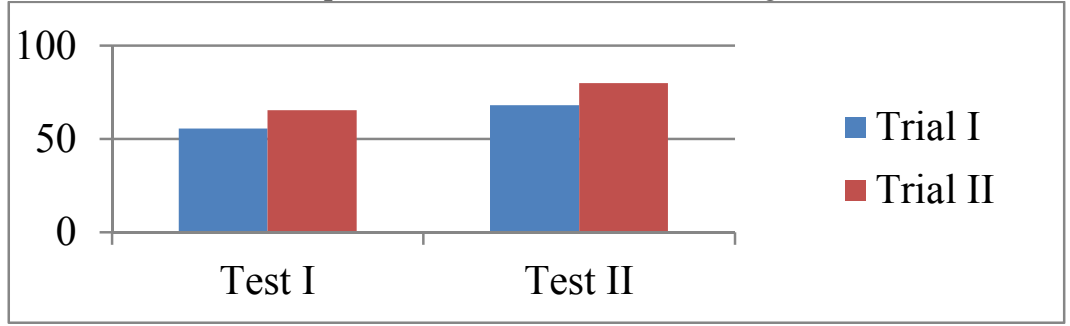

Picture 1. Improvement of Students' Spatial Mathematic Abilities Final Test Score

\section{Discussion}

\section{Development of Learning Media that is Valid, Practical, and Effective}

Based on the results of the analysis, it can be seen that the observation score of the implementation of learning has not met the criteria for practicality in trial I. Namely with a score of 2.67 at the first meeting, a score of 2.8 at the second meeting, and an average of 2.735 (category 'Poorly Performed'). Whereas in the second trial, a score of 3.53 was obtained at the first meeting, 3.8 at the second meeting, and 3.8 at the third meeting. The average result of observations of the implementation of learning in the second trial was 3.71 with the category "Well Done". These results have met the criteria for practical success. So, it can be concluded that the developed learning media based on Adobe Flash Pro CS6 are practical.

Based on the results of trial I and trial II, the learning media developed have met the effective category in terms of classical completeness, active student activity, the ability of teachers to manage learning well, and positive responses from teachers and students.

\section{Increased Spatial Abilities}

Based on the results of the analysis of the students 'mathematical spatial ability test in the first trial and the second trial, it showed that there was an increase in the students' mathematical spatial ability. This increase can be seen from the average spatial ability test results obtained by students. The increase in students' mathematic spatial abilities was also seen in each indicator of mathematic spatial abilities. Based on the normalized gain index, it was found that in the first trial there was an increase in the value with low criteria with a score of $0.28(\mathrm{~N}-\mathrm{Gain} \leq 0.3)$ and in the second trial there was an increase in the value with moderate criteria with a score of $0.42(0,3<\mathrm{N}-$ Gain $\leq 0.7)$. So it can be concluded that the developed learning media based on Adobe Flash Pro CS6 can improve students' mathematic spatial abilities.

Table 1. Increasing students' mathematic spatial abilities

\begin{tabular}{|c|c|c|c|}
\hline \multicolumn{2}{|c|}{ Uji Coba I } & \multicolumn{2}{c|}{ Uji Coba II } \\
\hline Skor & Category & Skor & Category \\
\hline 0,28 & Low & 0,42 & middle \\
\hline
\end{tabular}

\section{Conclusion}

1. The validation of learning media based on Adobe Flash Pro CS6 developed is in the 'Valid' category in terms of the analysis of the validity of the learning media by the validators with a total average value of 3.64 .

2. Learning media based on Adobe Flash Pro CS6 developed meets the criteria for practicality of learning media in terms of analysis of the results of observations of learning implementation. The score obtained in the first trial was 2,735 (category "Poorly Performed") and did not meet the criteria for the success of the study. However, after making several revisions, in the second trial the learning feasibility observation 
score increased to 3.71 ('Well Done'). So that the developed learning media successfully meets the criteria for practicality of learning media.

3. The learning media developed have met the set effectiveness criteria. In the first trial, the students' mathematic spatial ability was $53.33 \%$ (8 students) and in the second trial it was $86.67 \%$ (13 students). The average percentage of achieving the ideal time for student activities for the two meetings in the first trial was $24 \%, 29.2 \%, 25.7 \%, 10.42 \%, 6.25 \%$, and $3.48 \%$. Whereas in the second trial the average percentage of achieving the ideal time for student activities for the three meetings was $22.2 \%, 26.87 \%$, $26.87 \%, 13.9 \%, 7.87 \%$, and $2.32 \%$. The average score of the observation of the teacher's ability to manage learning was 3.31 (category 'Good') in trial I and 3.82 (category 'Good') in trial II. The mean teacher response was 3.56 (category "Interested") in Trial I and 3.67 (category "Interested") in Trial II. The average student responses were 3.69 (category "Interested") in Trial I and 3.71 (category "Interested") in Trial II.

4. The increase in students' mathematic spatial abilities was also seen in each indicator of mathematic spatial ability. Based on the normalized gain index, it was found that in the first trial there was an increase in the value with low criteria with a score of $0.28(\mathrm{~N}-\mathrm{Gain} \leq 0.3)$ and in the second trial there was an increase in the value with medium criteria with a score of $0.42(0,3<\mathrm{N}-\mathrm{Gain} \leq 0.7)$. So it can be concluded that the developed learning media based on Adobe Flash Pro CS6 can improve students' mathematic spatial ability

\section{REFERENCES}

Agung, T. (2013). Permainan Kreatif dan Edukatif untuk Anak Usia Dini. Yogyakarta: CV. Andi Offset. Arsyad, A. (2011). Media Pembelajaran. Jakarta: PT. Raja Grafindo Persada.

Cholila, A., Purwanto, Hidayanto, E. (2019). Media Pembelajaran Matematika Materi Kombinatorika Berbasis Media Interaktif pada Siswa SMK. Jurnal Pendidikan: Teori, Penelitian, dan Pengembangan. 4(4): 548-555.

Darmadi, H. (2017). Pengembangan Model dan Metode Pembelajaran dalam Dinamika Belajar Siswa. Yogyakarta: Deepublish.

Deiniatur, M. (2019). Developing Learning Media Through Macromedia Flash Application for English Phonology Class. Jurnal SMART. 5(1): 45-59.

Guzel, N., Sener, E. (2009). High School Students' Spatial Ability and Creativity in Geometry. Procedia Social and Behavioral Sciences 1: 1763-1766.Hamalik, O. (2008). Perencanaan Pengajaran Berdasarkan Pendekatan Sistem. Jakarta: PT. Bumi Aksara.

Istiqlal, M. (2017). Pengembangan Multimedia Interaktif dalam Pembelajaran Matematika. Jurnal Ilmiah Pendidikan Matematika. 2(1): 43-54.

Madcoms. (2013). Mahir dalam 7 Hari: Adobe Flash Professional CS6. Yogyakarta: Penerbit ANDI.

Murhaini, S. (2016). Menjadi Guru Profesional Berbasis Teknologi Informasi dan Komunikasi. Yogyakarta: Laksbang Pressindo.

Nurjanah, Dahlan, J.A., Wibisono, Y. (2017). Design and Development Computer-Based E-Learning Teaching Material for Improving Mathematical Understanding Ability and Spatial Sense of Junior High School Students. MSCEIS. IOP. Conf. Series: Journal of Physics: Conf. Series 812 (2017) 012098. DOI: 10.1088/1742-6596/812/1/012098.

Rezeki, S. (2018). Pemanfaatan Adobe Flash Professional CS6 Berbasis Problem Based Learning pada Materi Fungsi Komposisi dan Fungsi Invers. Jurnal Pendidikan Tambusai. 2(4): 509-936.

Santyasa, I.W. (2007). Landasan Konseptual Media Pembelajaran. Prosiding Workshop Media Pembelajaran. Bali: Universitas Pendidikan Ganesha.

Soenarto, Sunaryo. (2009). Pembelajaran Berbasis Multimedia sebagai Upaya Meningkatkan Kompetensi Hasil Belajar dan Persepsi Mahasiswa (Penelitian).

Susilana, R., Riyana, C. (2009). Media Pembelajaran Hakikat, Pemanfaatan dan Penilaian. Bandung: Wacana Prima.

Syahputra, E. (2011). Peningkatan Kemampuan Spasial dan Disposisi Matematis Siswa SMP dengan Pendekatan PMRI pada Pembelajaran Geometri Berbantuan Komputer [Tesis]. Bandung (ID): Universitas Pendidikan Indonesia.

Wardhani, G. W., Warjiyono. (2014). Perancangan Animasi Interaktif Berbentuk Puzzle Guna Melatih Kecerdasan Visual Spasial Anak. Evolusi. 11(1): 52-59. 